\title{
THE EXACT SOLUTION OF THE DIFFERENTIAL EQUATION OF THE COMPELLED CROSS VIBRATIONS OF THE CORE WITH ANY CONTINUOUS PARAMETERS
}

\author{
Yu. Krutii ${ }^{1}$, M. Surianinov ${ }^{1}$, V. Osadchiy ${ }^{1}$ \\ ${ }^{I}$ Odessa State Academy of Civil Engineering and Architecture
}

\begin{abstract}
The compelled cross vibrations of a core with any continuous variable parameters, loaded with evenly distributed harmonious loading are considered. The exact solution of the corresponding differential equation of vibrations in partial derivatives is constructed for the first time. As a result, in an analytical look formulas for dynamic movements and internal efforts in any section of a core are received. A practically important case is considered when the external dynamic load acting on the core is harmonic. For the external friction, the hypothesis is accepted according to which the resistance force is proportional to the mass and speed of the core, and the internal friction is taken into account according to the Kelvin-Voigt hypothesis, where the internal resistance force is proportional to the first degree of the strain rate.

As is known, the Kelvin-Voigt hypothesis in its pure form has several disadvantages. The main one is that it leads to a contradictory experimental data conclusion about the frequency-dependent internal friction in the material. This drawback can be eliminated if we accept the adjusted KelvinVoigt hypothesis, according to which the coefficient of internal friction is chosen inversely proportional to the frequency with which the structure oscillates.

The dynamic parameters of the core are fully defined. The obtained formulas contain unknown constants in the form of initial values of real and imaginary components (initial parameters). Additionally, the formulas which are equivalent to them are proposed. They are recommended for practical use during the study of the oscillations, which are different, the amplitude functions of dynamic parameters are clearly distinguished in them.

The solution of this problem opens up the prospect of creating a new method for studying the transverse vibrations of the cores with arbitrary continuous parameters taking into account the resistances. For this purpose, it is sufficiently to indicate an effective method for the numerical implementation of the exact solutions.

The integration of fourth-order linear ordinary differential equations with variable coefficients leads to problems associated with calculating the parameters of various systems; therefore, the method for solving the problem proposed in the article has a value that goes far beyond the limits of the considered problem.
\end{abstract}

Keywords: cross vibrations of a core, variable parameters, harmonic load, equation of oscillations, Kelvin-Voigt hypothesis, exact solution.

\section{ТОЧНИЙ РОЗВ' ЯЗОК ДИФЕРЕНЦІАЛЬНОГО РІВНЯННЯ ВИМУШЕНИХ ПОПЕРЕЧНИХ КОЛИВАНЬ СТРИЖНЯ 3 ДОВІЛЬНИМИ НЕПЕРЕРВНИМИ ПАРАМЕТРАМИ}

\author{
Крутій Ю. С. ${ }^{1}$, Сур'янінов М. Г. ${ }^{1}$, Осадчий В. С. ${ }^{1}$ \\ ${ }^{1}$ Одеська державна академія будівництва та архітектури
}

Аннотація: Розглядаються вимушені поперечні коливання стрижня 3 довільними неперервними змінними параметрами, навантаженого рівномірно розподіленим гармонійним навантаженням. Вперше побудовано точний розв'язок відповідного диференціального рівняння коливань в частинних похідних. Як наслідок, в 
аналітичному вигляді одержано формули для динамічних переміщень і внутрішніх зусиль в довільному перерізі стержня. Розглянуто практично важливий випадок, коли діюче на стрижень зовнішня динамічне навантаження $є$ гармонійним. Для зовнішнього тертя приймається гіпотеза, згідно 3 якою сила опору пропорційна масі стрижня i швидкості, а внутрішнє тертя враховується за гіпотезою Кельвіна-Фохта, згідно з якою сила внутрішнього опору пропорційна першому степеню швидкості деформації.

Як відомо, гіпотеза Кельвіна-Фохта в іiі чистому вигляді має ряд недоліків. Головний з них полягає в тому, що вона призводить до суперечливого дослідним даним висновку про частотно-залежне внутрішне тертя в матеріалі. Зазначений недолік може бути усунутий, якщо прийняти скориговану гіпотезу Кельвіна-Фохта, згідно з якою коефіцієнт внутрішнього тертя вибирається обернено пропорційним частоті, 3 якою коливається конструкція.

Повністю визначені динамічні параметри стрижня. Отримані формули містять невідомі сталі у вигляді початкових значень дійсних і уявних складових (початкові параметри). Додатково запропоновані рівносильні їм формули, які рекомендуються для практичного застосування при дослідженні коливань, які відрізняються тим, що в них явно виділені амплітудні функції динамічних параметрів.

Розв'язок поставленої проблеми відкриває перспективу для створення нового методу дослідження поперечних коливань стрижнів 3 довільними неперервними параметрами з урахуванням опорів. Для цього достатньо вказати ефективний метод чисельної реалізації знайдених в роботі точних розв'язків.

До інтегрування лінійних звичайних диференціальних рівнянь четвертого порядку зі змінними коефіцієнтами призводять завдання, пов'язані з розрахунками параметрів різноманітних систем, тому запропонований в статті метод розв'язання задачі має значення, що виходить далеко за межі розглянутої проблеми.

Ключові слова: Вимушені коливання стрижня, змінні параметри, гармонійне навантаження, рівняння коливань, гіпотеза Кельвіна-Фохта, точний розв'язок. 


\section{INTRODUCTION}

It is commonly known, the estimation of bearing ability of any design typically involves issues of strength, stability and dynamics. Historically, the most structural elements in various branches of technology were carried out with the constant geometric parameters in terms of cross section. From the mathematical point of view, in the calculations it leads to differential equations (or their systems) with the constant coefficients. The exact solutions of such equations are made in many cases. If it is impossible to do the approximate or numerical methods are used.

However, the development of technology, the construction of large buildings, the success of aviation, aerospace, shipbuilding have highlighted the issue of reduction in consumption of materials. One of the most effective ways to achieve this goal is the design of systems with variable parameters, in particular, variable stiffness. In the calculations of such systems the differential equations (or systems of equations) with variable coefficients have to be dealt with. The success of mathematics in the solution of these equations looks rather modestly. Only certain special cases of the construction of exact solutions are known. This work is devoted to the actual problem, namely, the formation of exact solution of the differential equation of core's forced transverse vibrations with arbitrary continuous parameters.

\section{LITERATURE DATA ANALYSIS AND TARGET SETTING}

The integration of linear ordinary fourth-order differential equations with variable coefficients is led by the problems associated with calculating the parameters of various core systems, which are of great practical importance for various fields of technology. We note the work of I. Babakov [1], T. Danilevich [2], O. Galas [3], G. Maslov [4], V. Svetlitskii [5-6], E. Kharchenko [7-9], F. Shevchenko [10]. Asymptotic or numerical methods of solution are used in these works.

This article is devoted to the compelled cross vibrations of direct, generally speaking, non-uniform core of variable cross section of length $l$, taking into account resistances.

We will combine an axis $x$ with the line of the centers of gravity of cross sections of a core and we will consider that its ends lie in points $x=0$ and $x=l$. Downward deflections of the core are considered to be positive deflections.

The general scheme of vibrations is submitted in fig. 1. in fig. 2 the scheme of operating efforts to a core element is represented at fluctuations.

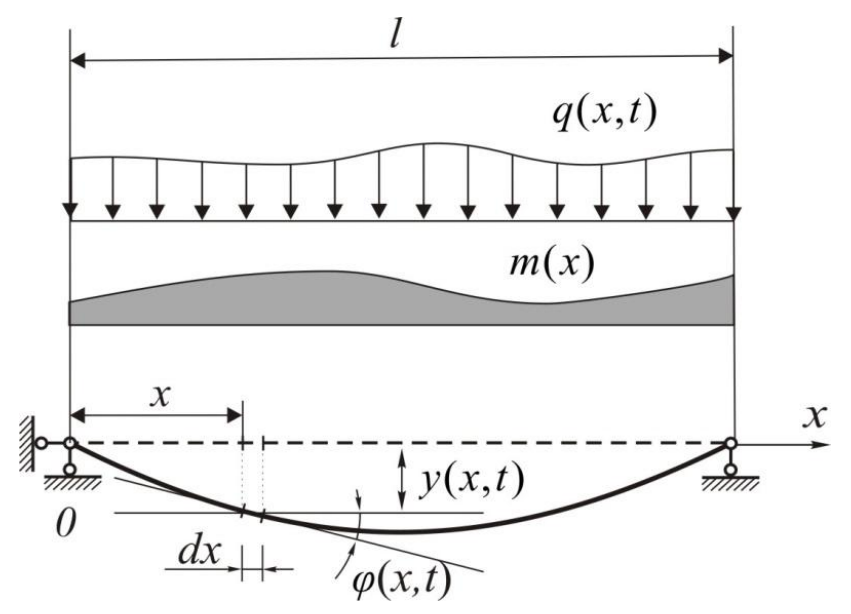

Fig. 1. Forced cross vibrations of the core 


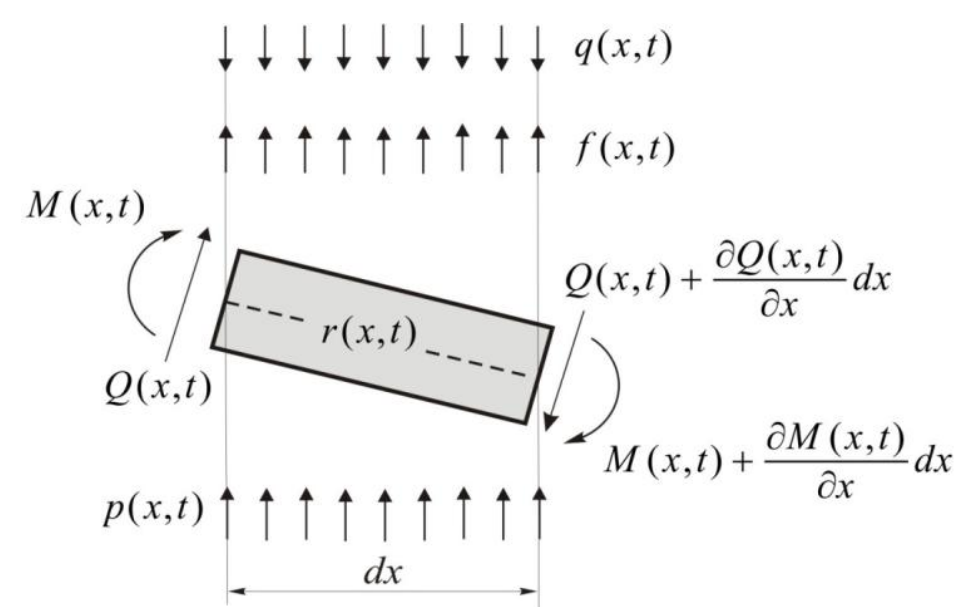

Fig. 2. Scheme of operating efforts to a core element

Here are the following notations:

$q(x, t)$-intensity of dynamic transversal loading reaction operating on a core;

$m(x)$-intensity of the distributed core weight (weight per unit weight);

$y(x, t)$ - transversal movement of a point of the core axle with coordinate $x$ in an instant $t$ (a dynamic deflection);

$\varphi(x, t)$-dynamic angle of rotation;

$M(x, t)$-dynamic moment of deflection;

$Q(x, t)$ - dynamic cross force;

$r(x, t)$-intensity of forces of internal resistance;

$p(x, t)$-intensity of external forces of resistance to move;

$f(x, t)=-m(x) \frac{\partial^{2} y}{\partial t^{2}}-$ intensity of the inertial forces arising in the course of fluctuations (strength of D'Alembert).

The corresponding differential equation of the cross vibrations, taking into consideration resistance, is [1-3]:

$$
\frac{\partial^{2}}{\partial x^{2}}\left(E(x) I(x) \frac{\partial^{2} y}{\partial x^{2}}\right)+m(x) \frac{\partial^{2} y}{\partial t^{2}}+p(x, t)+r(x, t)=q(x, t),
$$

where $E(x) I(x)$ variable cross rigidity of a core;

$E(x)$ - module of material elasticity of a core;

$I(x)$ - moment of inertia of cross section of a core.

The equation (1) is true for model in which it is accepted to neglect longitudinal movements of sections, their turns and shifts.

We will consider practically important case when external dynamic loading operating on a core is harmonious

$$
q(x, t)=q(x) \sin \theta t
$$

where $q(x)$ - continuous amplitude function of cross loading;

$\theta$ - frequency of the disturbing force.

For external, friction we accept a hypothesis according to which force of resistance is proportional to the mass of a core and speed [11], and we will consider internal friction on 
Kelvin-Voigt hypothesis [12] according to which force of internal resistance is proportional to the first degree of speed of deformation. In that case for intensity of forces of resistance we will have:

$$
p(x, t)=\alpha m(x) \frac{\partial y}{\partial t} ; r(x, t)=\beta \frac{\partial}{\partial t}\left[\frac{\partial^{2}}{\partial x^{2}}\left(E(x) I(x) \frac{\partial^{2} y}{\partial x^{2}}\right)\right],
$$

where $\alpha, \beta$-constant coefficients of external and internal friction respectively.

Equation (1) taking into account (2), (3) assumes following form

$$
\left(1+\beta \frac{\partial}{\partial t}\right) \frac{\partial^{2}}{\partial x^{2}}\left(E(x) I(x) \frac{\partial^{2} y}{\partial x^{2}}\right)+m(x) \frac{\partial^{2} y}{\partial t^{2}}+\alpha m(x) \frac{\partial y}{\partial t}=q(x) \sin \theta t .
$$

Let cross rigidity $E(x) I(x)$, running mass of the core $m(x)$ and amplitude function of loading $q(x)$ represent any continuous functions of coordinate $x$.

However, as we know, it is not possible to find exact solutions of differential equations with variable coefficients in the most cases. This circumstance was one of the main reasons for rapid development of approximate methods.

Above mentioned is also fully applicable to the equation (4). For example, in widely known monograph [13], in regard to the special case of the equation (4) when $\alpha=\beta=0$ and $q(x) \equiv 0$, they say that it is possible to receive the exact solution only in some special cases. Therefore the performance task, even in that specific case $\alpha=\beta=0$ and $q(x)=0$, represents a difficult and actual scientific problem. It is quite clear that the existence of transversal loading and resisting forces in the equation (4) only complicate this problem.

Kelvin - Voigt hypothesis in its pure form is reported to have several disadvantages $[15,16]$. The main one is that it leads to a contradictory experimental data conclusion about the frequency-dependent internal friction in the material. This disadvantage can be avoided if we accept the adjusted Kelvin - Voigt hypothesis [15], according to which the coefficient $\beta$ is chosen inversely proportional to the frequency with which the structure oscillates. Accepting the version of frequency-independent friction for external forces [15], for the coefficients of external and internal friction we assume:

where $v$-is the coefficient of inelastic resistance of the circumscription, $\gamma-$ is the coefficient of inelastic resistance of the material of the rod.

\section{PURPOSE AND OBJECTIVES OF RESEARCH}

The purpose of this article is to construct an accurate solution of forced transverse vibrations of the core with arbitrary continuous variable parameters, loaded with a uniformly distributed harmonic load. Using the predicted solution, it is required to obtain the formulas in an analytical form for dynamic displacements and dynamic internal forces in an arbitrary section of the core.

\section{RESEARCH RESULTS}

The solution of the equation (4) will be found out with the generalized separation of the variables

$$
y(x, t)=y_{1}(x) \sin \theta t+y_{2}(x) \cos \theta t,
$$

where $y_{1}(x), y_{2}(x)$ - are unknown functions depending only on a variable $x$. 
Having accepted the formula for a dynamic deflection in the form of (5), for other dynamic parameters of core's state, namely, for the angle of rotation, deflection moment and transversal force, there will be:

$$
\begin{aligned}
& \varphi(x, t)=\varphi_{1}(x) \sin \theta t+\varphi_{2}(x) \cos \theta t ; \\
& M(x, t)=M_{1}(x) \sin \theta t+M_{2}(x) \cos \theta t ; \\
& Q(x, t)=Q_{1}(x) \sin \theta t+Q_{2}(x) \cos \theta t,
\end{aligned}
$$

where

$$
\varphi_{j}(x)=y_{j}^{\prime}(x) ; \quad M_{j}(x)=-E(x) I(x) \varphi_{j}^{\prime}(x) ; \quad Q_{j}(x)=M_{j}^{\prime}(x) \quad(j=1,2) .
$$

Therefore, the dynamic parameters will be defined completely by the functions $y_{j}(x), \varphi_{j}(x), M_{j}(x), Q_{j}(x),(j=1,2)$, which we will call components for the dynamic parameters.

Substituting in the equation (4) its representation (5) instead of unknown function $y(x, t)$, after apparent transformations, there will be

$$
\begin{aligned}
& {\left[\left(E(x) I(x) y_{1}^{\prime \prime}(x)\right)^{\prime \prime}-\theta^{2} m(x)\left(y_{1}(x)+v y_{2}(x)\right)-\gamma\left(E(x) I(x) y_{2}^{\prime \prime}(x)\right)^{\prime \prime}-q(x)\right] \sin \theta t+} \\
& +\left[\left(E(x) I(x) y_{2}^{\prime \prime}(x)\right)^{\prime \prime}-\theta^{2} m(x)\left(y_{2}(x)-v y_{1}(x)\right)+\gamma\left(E(x) I(x) y_{1}^{\prime \prime}(x)\right)^{\prime \prime}\right] \cos \theta t=0 .
\end{aligned}
$$

This equality is obliged to be for any value $t$, that can be achieved, only having equated to zero multipliers at the functions $\sin \theta t$ and $\cos \theta t$. After that we will have the system of two differential equations which we will write down in a matrix form

$$
\left(\begin{array}{cc}
1 & -\gamma \\
\gamma & 1
\end{array}\right)\left(\begin{array}{l}
\left(E(x) I(x) y_{1}^{\prime \prime}(x)\right)^{\prime \prime} \\
\left(E(x) I(x) y_{2}^{\prime \prime}(x)\right)^{\prime \prime}
\end{array}\right)=\theta^{2} m(x)\left(\begin{array}{cc}
1 & v \\
-v & 1
\end{array}\right)\left(\begin{array}{l}
y_{1}(x) \\
y_{2}(x)
\end{array}\right)+\left(\begin{array}{c}
q(x) \\
0
\end{array}\right) \text {. }
$$

The constant matrixes, appearing in the record of system, are given by the uniform homothetic transformation to a diagonal look:

$$
S^{-1}\left(\begin{array}{cc}
1 & -\gamma \\
\gamma & 1
\end{array}\right) S=\left(\begin{array}{cc}
1+i \gamma & 0 \\
0 & 1-i \gamma
\end{array}\right) ; \quad S^{-1}\left(\begin{array}{rr}
1 & v \\
-v & 1
\end{array}\right) S=\left(\begin{array}{cc}
1-i v & 0 \\
0 & 1+i v
\end{array}\right),
$$

where $S=\left(\begin{array}{cc}1 & 1 \\ -i & i\end{array}\right)-$ is transforming matrix ( $i$ - imaginary unit). Thereof, carrying out the substitution (9)

$$
\left(\begin{array}{l}
y_{1}(x) \\
y_{2}(x)
\end{array}\right)=S\left(\begin{array}{l}
z(x) \\
z(x)
\end{array}\right)
$$

where

$$
z(x)=\frac{y_{1}(x)+i y_{2}(x)}{2}, \overline{z(x)}=\frac{y_{1}(x)-i y_{2}(x)}{2},
$$

- new unknown functions, we come to two self-contained equations

$$
(1+i \gamma)\left(\left(E(x) I(x) z^{\prime \prime}(x)\right)^{\prime \prime}-\theta^{2}(1-i v) m(x) z(x)=\frac{q(x)}{2},\right.
$$




$$
(1-i \gamma)(E(x) I(x) \overline{z(x)})^{\prime \prime}-\theta^{2}(1+i v) m(x) \overline{z(x)}=\frac{q(x)}{2}
$$

It is important to notice that each of the equations (11), (12) is derived from another one by the method of complex conjugation. Therefore, if $z(x)$-is the solution of the first equation, the solution of the second will be $\overline{z(x)}$, and vice versa. Therefore it makes sense to consider only one of these equations.

Let's choose for further consideration the equation (11), which we will copy as follow

$$
\left(E(x) I(x) z^{\prime \prime}(x)\right)^{\prime \prime}-\lambda^{2} m(x) z(x)=\frac{q(x)}{2(1+i \gamma)},
$$

where $\lambda^{2}=\theta^{2} \frac{1-i v}{1+i \gamma}$.

Let's put in compliance to the equation (13) The system of differential equations equivalent to it. Thus as a vector of indeterminate we will accept the following vector

$$
Z(x)=\left(\begin{array}{c}
z(x) \\
z^{\prime}(x) \\
-E(x) I(x) z^{\prime \prime}(x) \\
-\left(E(x) I(x) z^{\prime \prime}(x)\right)^{\prime}
\end{array}\right) .
$$

Then

$$
\frac{d Z(x)}{d x}=P(x) Z(x)-f(x),
$$

where

$$
P(x)=\left(\begin{array}{cccc}
0 & 1 & 0 & 0 \\
0 & 0 & -\frac{1}{E(x) I(x)} & 0 \\
0 & 0 & 0 & 1 \\
-\lambda^{2} m(x) & 0 & 0 & 0
\end{array}\right), f(x)=\frac{q(x)}{2(1+i \gamma)}\left(\begin{array}{l}
0 \\
0 \\
0 \\
1
\end{array}\right) .
$$

At the beginning we will find the fundamental solutions of the homogeneous equation

$$
\left(E(x) I(x) z^{\prime \prime}(x)\right)^{\prime \prime}-\lambda^{2} m(x) z(x)=0,
$$

to which the homogeneous system will be corresponded

$$
\frac{d Z(x)}{d x}=P(x) Z(x) \text {. }
$$

For this purpose we will insert into consideration four infinite systems of unknowns for four times continuously differentiable functions $b_{n, 0}(x), b_{n, k}(x)(n=1,2,3,4)(k=1,2,3, \ldots)$. By means of these functions and their derivatives we form the following ranks on parameter degrees $\lambda^{2}$ :

$$
\begin{aligned}
& U_{n}(x)=b_{n, 0}(x)+\lambda^{2} b_{n, 1}(x)+\lambda^{4} b_{n, 2}(x)+\lambda^{6} b_{n, 3}(x)+\cdots ; \\
& U_{n}^{\prime}(x)=b_{n, 0}^{\prime}(x)+\lambda^{2} b_{n, 1}^{\prime}(x)+\lambda^{4} b_{n, 2}^{\prime}(x)+\lambda^{6} b_{n, 3}^{\prime}(x)+\cdots ; \\
& U_{n}^{\prime \prime}(x)=b_{n, 0}^{\prime \prime}(x)+\lambda^{2} b_{n, 1}^{\prime \prime}(x)+\lambda^{4} b_{n, 2}^{\prime \prime}(x)+\lambda^{6} b_{n, 3}^{\prime \prime}(x)+\cdots ;
\end{aligned}
$$




$$
\begin{aligned}
& \left(E(x) I(x) U_{n}^{\prime \prime}(x)\right)^{\prime}=\left(E(x) I(x) b_{n, 0}^{\prime \prime}(x)\right)^{\prime}+\lambda^{2}\left(E(x) I(x) b_{n, 1}^{\prime \prime}(x)\right)^{\prime}+ \\
& +\lambda^{4}\left(E(x) I(x) b_{n, 2}^{\prime \prime}(x)\right)^{\prime}+\cdots ; \\
& \left(E(x) I(x) U_{n}^{\prime \prime}(x)\right)^{\prime \prime}=\left(E(x) I(x) b_{n, 0}^{\prime \prime}(x)\right)^{\prime \prime}+\lambda^{2}\left(E(x) I(x) b_{n, 1}^{\prime \prime}(x)\right)^{\prime \prime}+ \\
& +\lambda^{4}\left(E(x) I(x) b_{n, 2}^{\prime \prime}(x)\right)^{\prime \prime}+\cdots .
\end{aligned}
$$

So we assume that all the ranks evenly converge on the segment $x \in[0, l]$.

Unknown functions $b_{n, 0}(x), b_{n, k}(x)(n=1,2,3,4)(k=1,2,3, \ldots)$ Will be found from the statement that $U_{n}(x)$ Satisfies the equation (16), that is

$$
\left(E(x) I(x) U_{n}^{\prime \prime}(x)\right)^{\prime \prime}-\lambda^{2} m(x) U_{n}(x)=0 \quad(n=1,2,3,4) .
$$

Then, taking into account the formulas (18), (22), we come to solve the equality

$$
\left(E(x) I(x) b_{n, 0}^{\prime \prime}(x)\right)^{\prime \prime}+\sum_{k=1}^{\infty} \lambda^{2 k}\left(\left(E(x) I(x) b_{n, k}^{\prime \prime}(x)\right)^{\prime \prime}-m(x) b_{n, k-1}(x)\right)=0 .
$$
have:

Thus, equating to zero all the coefficients at degrees $\lambda^{2}$, including zero degree, we will

$$
\begin{aligned}
& \left(E(x) I(x) b_{n, 0}^{\prime \prime}(x)\right)^{\prime \prime}=0 ; \\
& \left(E(x) I(x) b_{n, k}^{\prime \prime}(x)\right)^{\prime \prime}=m(x) b_{n, k-1}(x) \quad(k=1,2,3, \ldots) .
\end{aligned}
$$

It is easy to write out fundamental system of solutions (24). Before integrating the equation (25), for all $n=1,2,3,4$ we will set boundary conditions

$$
b_{n, k}(0)=b_{n, k}^{\prime}(0)=E(0) I(0) b_{n, k}^{\prime \prime}(0)=\left(E(0) I(0) b_{n, k}^{\prime \prime}(0)\right)^{\prime}=0(k=1,2,3, \ldots) .
$$

As a result we will have:

$$
\begin{aligned}
& b_{n, 0}(x)=x^{n-1}(n=1,2), b_{n, 0}(x)=\int_{0}^{x} \int_{0}^{x} \frac{x^{n-3}}{E(x) I(x)} d x d x(n=3,4) ; \\
& b_{n, k}(x)=\int_{0}^{x} \int_{0}^{x} \frac{1}{E(x) I(x)} \int_{0}^{x} \int_{0}^{x} m(x) b_{n, k-1}(x) d x d x d x d x(k=1,2,3, \ldots) .
\end{aligned}
$$

Thus, accordingly to the recursion formula (28), each initial function $b_{n, 0}(x)$ has its own multiplicity of functions $b_{n, k}(x)(k=1,2,3, \ldots)$ which will be called generating. For such functions the equalities (23) are identically kept under the formation.

For descriptive reasons we will write down the formula (28) also in expanded form

$$
b_{n, k}(x)=\int_{0}^{x} \int_{0}^{x} \frac{1}{E(x) I(x)} \int_{0}^{x} \int_{0}^{x} m(x) \ldots \int_{0}^{x} \int_{0}^{x} \frac{1}{E(x) I(x)} \int_{0}^{x} \int_{0}^{x} m(x) b_{n, 0}(x) d x d x d x d x \ldots d x d x d x d x .
$$

The number of integrals in this formula, without considering the integrals which may contain initial functions, is equal to $4 k$.

We investigate now a row (18) as for convergence. To construct majorant row, the positive constants will be used.

$$
g_{1}=\max _{x \in[0, l]} m(x), g_{2}=\max _{x \in[0, l]} \frac{1}{E(x) I(x)}, h_{n}=\max _{x \in[0, l]}\left|b_{n, 0}(x)\right| .
$$

Then for forming functions (30) from the formula there are some estimates 


$$
\left|b_{n, k}(x)\right| \leq h_{n}\left(g_{1} g_{2}\right)^{k}\left|\int_{0}^{x} \int_{0}^{x} \int_{0}^{x} \int_{0}^{x} \ldots \int_{0}^{x} \int_{0}^{x} \int_{0}^{x} \int_{0}^{x} d x d x \ldots d x d x\right|=h_{n}\left(g_{1} g_{2}\right)^{k} \frac{x^{4 k}}{(4 k) !}(k=1,2,3, \ldots) .
$$

Hence, for the row, made from the modules we receive

$$
\begin{aligned}
& \left|b_{n, 0}(x)\right|+\left|\lambda^{2} b_{n, 1}(x)\right|+\left|\lambda^{4} b_{n, 2}(x)\right|+\cdots \leq h_{n}\left(1+g_{1} g_{2} \lambda^{2} \frac{x^{4}}{4 !}+\left(g_{1} g_{2}\right)^{2} \lambda^{4} \frac{x^{8}}{8 !}+\cdots\right)= \\
& =\frac{h_{n}}{2}\left(\operatorname{ch} \sqrt[4]{g_{1} g_{2} \lambda^{2}} x+\cos \sqrt[4]{g_{1} g_{2} \lambda^{2}} x\right) .
\end{aligned}
$$

The majorant one within the multiplier is apparently the sum of the elementary functions. Each of them is defined by the row which evenly meets. Therefore, the row made of modules also meets evenly. The ranks (18) are proved to meet absolutely and evenly.

Similarly it is possible to prove absolute and uniform convergence of the ranks (19) (21). Convergence of the row (22) does not demand the separate proof as it, according to the identity (23), differs from the row (18) only by a multiplier. As a result, ranks (18) - (21) can be differentiated termwise, so, the designations, $U_{n}^{\prime}(x), U_{n}^{\prime \prime}(x),\left(E(x) I(x) U_{n}^{\prime \prime}(x)\right)^{\prime}$, $\left(E(x) I(x) U_{n}^{\prime \prime}(x)\right)^{\prime \prime}$ for ranks (19) - (22) are true.

Therefore, four solutions $U_{n}(x)(n=1,2,3,4)$ of the equation (16) are defined by formulas (18), (27) - (29). According to formula (14) we receive four vectors - system solutions (17)

$$
Z_{n}(x)=\left(\begin{array}{c}
U_{n}(x) \\
U_{n}^{\prime}(x) \\
-E(x) I(x) U_{n}^{\prime \prime}(x) \\
-\left(E(x) I(x) U_{n}^{\prime \prime}(x)\right)^{\prime}
\end{array}\right)(n=1,2,3,4) .
$$

Then the matrix, made of these vectors,

$$
\Omega(x)=\left\|Z_{1}(x) Z_{2}(x) Z_{3}(x) Z_{4}(x)\right\|,
$$

also satisfies the system.

Let's calculate the value $\Omega(0)$. For this purpose at the beginning the formula for calculation $Z_{n}(0)(n=1,2,3,4)$ has to be worked out. Having $x=0$ in formulas (18) - (21) and considering boundary conditions (26), we receive

$$
Z_{n}(0)=\left(\begin{array}{c}
U_{n}(0) \\
U_{n}^{\prime}(0) \\
-E(0) I(0) U_{n}^{\prime \prime}(0) \\
-\left(E(0) I(0) U_{n}^{\prime \prime}(0)\right)^{\prime}
\end{array}\right)=\left(\begin{array}{c}
b_{n, 0}(0) \\
b_{n, 0}^{\prime}(0) \\
-E(0) I(0) b_{n, 0}^{\prime \prime}(0) \\
-\left(E(0) I(0) b_{n, 0}^{\prime \prime}(0)\right)^{\prime}
\end{array}\right) .
$$

Hence

$$
Z_{1}(0)=\left(\begin{array}{l}
1 \\
0 \\
0 \\
0
\end{array}\right), Z_{2}(0)=\left(\begin{array}{l}
0 \\
1 \\
0 \\
0
\end{array}\right), Z_{3}(0)=\left(\begin{array}{c}
0 \\
0 \\
-1 \\
0
\end{array}\right), Z_{4}(0)=\left(\begin{array}{c}
0 \\
0 \\
0 \\
-1
\end{array}\right) .
$$

Therefore, 


$$
\Omega(0)=\left(\begin{array}{cccc}
1 & 0 & 0 & 0 \\
0 & 1 & 0 & 0 \\
0 & 0 & -1 & 0 \\
0 & 0 & 0 & -1
\end{array}\right)
$$

For Wronskian $W(x)=|\Omega(x)|$, considering equality (32), we receive $W(0)=1 \neq 0$. So the vectors (30) are independent linearly. The matrix $\Omega(x)$ is a fundamental matrix of system (17).

Multiplying on the right $\Omega(x)$ by a constant matrix $\Omega^{-1}(0)$, we will receive a new fundamental matrix

$$
\Lambda(x)=\left(\begin{array}{cccc}
U_{1}(x) & U_{2}(x) & -U_{3}(x) & -U_{4}(x) \\
U_{1}^{\prime}(x) & U_{2}^{\prime}(x) & -U_{3}^{\prime}(x) & -U_{4}^{\prime}(x) \\
-E(x) I(x) U_{1}^{\prime \prime}(x) & -E(x) I(x) U_{2}^{\prime \prime}(x) & E(x) I(x) U_{3}^{\prime \prime}(x) & E(x) I(x) U_{4}^{\prime \prime}(x) \\
-\left(E(x) I(x) U_{1}^{\prime \prime}(x)\right)^{\prime} & -\left(E(x) I(x) U_{2}^{\prime \prime}(x)\right)^{\prime} & \left(E(x) I(x) U_{3}^{\prime \prime}(x)\right)^{\prime} & \left(E(x) I(x) U_{4}^{\prime \prime}(x)\right)^{\prime}
\end{array}\right),
$$

for which

$$
\Lambda(0)=\left(\begin{array}{llll}
1 & 0 & 0 & 0 \\
0 & 1 & 0 & 0 \\
0 & 0 & 1 & 0 \\
0 & 0 & 0 & 1
\end{array}\right)
$$

The fundamental matrix, meeting the condition (33), is unambiguously and is called as a matrizant [17]. Considering that, $\operatorname{SpP}(x)=0$ for the determinant of the matrizant by formula of Jacobi [17] we have

$$
W(x)=|\Lambda(x)|=|\Lambda(0)| \exp \left(\int_{0}^{x} \operatorname{Sp} P(x) d x\right)=1 .
$$

Using the properties of the determinants, it is possible to establish the dependence between Wronskian $W(x)$ of vector system (30) and Wronskian $w(x)$ of function system $U_{n}(x) \quad(n=1,2,3,4)$

$$
w(x)=\left|\begin{array}{cccc}
U_{1}(x) & U_{2}(x) & U_{3}(x) & U_{4}(x) \\
U_{1}^{\prime}(x) & U_{2}^{\prime}(x) & U_{3}^{\prime}(x) & U_{4}^{\prime}(x) \\
U_{1}^{\prime \prime}(x) & U_{2}^{\prime \prime}(x) & U_{3}^{\prime \prime}(x) & U_{4}^{\prime \prime}(x) \\
U_{1}^{\prime \prime \prime}(x) & U_{2}^{\prime \prime \prime}(x) & U_{3}^{\prime \prime \prime}(x) & U_{4}^{\prime \prime \prime}(x)
\end{array}\right|
$$

This dependence will be expressed by the equality $W(x)=(E(x) I(x))^{2} w(x)$. Then taking into account (34) We receive $w(x)=1 /(E(x) I(x))^{2} \neq 0$.

As the linear independence of the relevant system of functions [17] follows from an inequality to zero of Wronskian, functions $U_{n}(x)(n=1,2,3,4)$ are independent linearly, so, they form fundamental system of solutions of the equation (16).

For the specific solution of the nonuniform equation (13) there is

$$
U_{*}(x)=\frac{1}{2(1+i \gamma)} U_{5}(x) \text {. }
$$


Thus $U_{5}(x)$ by analogy to the formula (18) we will search as follows

$$
U_{5}(x)=b_{5,0}(x)+\lambda^{2} b_{5,1}(x)+\lambda^{4} b_{5,2}(x)+\lambda^{6} b_{5,3}(x)+\cdots,
$$

where the functions $b_{5, k}(x)(k=0,1,2, \ldots)$ can be defined.

Substituting the value $U_{*}(x)$ in the equation (13), we will receive

$$
\left(E(x) I(x) b_{5,0}^{\prime \prime}(x)\right)^{\prime \prime}-q(x)+\sum_{k=1}^{\infty} \lambda^{2 k}\left(\left(E(x) I(x) b_{5, k}^{\prime \prime}(x)\right)^{\prime \prime}-m(x) b_{5, k-1}^{\prime \prime}(x)\right)=0 \text {. }
$$

For satisfaction of this equality, it is necessary to equate to zero all the coefficients at degrees $\lambda^{2}$, starting from zero degree. The coefficient at zero degree is apparently equal to $\left(E(x) I(x) b_{5,0}^{\prime \prime}(x)\right)^{\prime \prime}-q(x)$. Therefore, we will have:

$$
\begin{aligned}
& \left(E(x) I(x) b_{5,0}^{\prime \prime}(x)\right)^{\prime \prime}=q(x) ; \\
& \left(E(x) I(x) b_{5, k}^{\prime \prime}(x)\right)^{\prime \prime}=m(x) b_{5, k-1}^{\prime \prime}(x)(k=1,2,3, \ldots) .
\end{aligned}
$$

The quality (38) is similar to the equality (25) by its form, and the equality (37) differs from the equality (24) by existence of a right part. For required forming functions $b_{5, k}(x)(k=1,2,3, \ldots)$ the formulas $(28),(29)$ will be fair but taking into account $n=5$. We will choose the following partial solution of the equation (37) as an initial function

$$
b_{5,0}(x)=\int_{0}^{x} \int_{0}^{x} \frac{1}{E(x) I(x)} \int_{0}^{x} \int_{0}^{x} q(x) d x d x d x d x .
$$

But the property of an initial function is

$$
b_{5,0}(0)=b_{5,0}^{\prime}(0)=E(0) I(0) b_{5,0}^{\prime \prime}(0)=\left(E(0) I(0) b_{5,0}^{\prime \prime}(0)\right)^{\prime}=0 \text {. }
$$

Thereby, the partial solution of the equation (13) is found. According to the known partial solution (35) we form a vector

$$
\Psi_{5}(x)=\frac{1}{2(1+i \beta \theta)}\left(\begin{array}{c}
U_{5}(x) \\
U_{5}^{\prime}(x) \\
-E(x) I(x) U_{5}^{\prime \prime}(x) \\
-\left(E(x) I(x) U_{5}^{\prime \prime}(x)\right)^{\prime}
\end{array}\right),
$$

which will be the partial solution of the system (15), what can be easily proved by the substitution. Besides, taking into account (31), (39), there is

$$
\Psi_{5}(0)=\frac{1}{2(1+i \beta \theta)}\left(\begin{array}{c}
U_{5}(0) \\
U_{5}^{\prime}(0) \\
-E(0) I(0) U_{5}^{\prime \prime}(0) \\
-\left(E(0) I(0) U_{5}^{\prime \prime}(0)\right)^{\prime}
\end{array}\right)=\left(\begin{array}{l}
0 \\
0 \\
0 \\
0
\end{array}\right) .
$$

Finally, the general solution of the system (15) looks like [17]

$$
Z(x)=\Lambda(x) Z(0)+\Psi_{5}(x) .
$$

On the other hand, differentiating the first formulas (10) and considering thus for the vector $Z(x)$ we will receive 


$$
Z(x)=\left(\begin{array}{c}
z(x) \\
z^{\prime}(x) \\
-E(x) I(x) z^{\prime \prime}(x) \\
-\left(E(x) I(x) z^{\prime \prime}(x)\right)^{\prime}
\end{array}\right)=\frac{1}{2}\left(\begin{array}{l}
y_{1}(x)+i y_{2}(x) \\
\varphi_{1}(x)+i \varphi_{2}(x) \\
M_{1}(x)+i M_{2}(x) \\
Q_{1}(x)+i Q_{2}(x)
\end{array}\right) .
$$

Having regard to (41), the matrix equality (40) Has to be rewritten in extended form. As a result we will come to the formulas:

$$
\begin{aligned}
& \frac{y_{1}(x)+i y_{2}(x)}{2}=\frac{y_{1}(0)+i y_{2}(0)}{2} U_{1}(x)+\frac{\varphi_{1}(0)+i \varphi_{2}(0)}{2} U_{2}(x)- \\
& -\frac{M_{1}(0)+i M_{2}(0)}{2} U_{3}(x)-\frac{Q_{1}(0)+i Q_{2}(0)}{2} U_{4}(x)+\frac{1}{2(1+i \gamma)} U_{5}(x) \\
& \frac{\varphi_{1}(x)+i \varphi_{2}(x)}{2}=\frac{y_{1}(0)+i y_{2}(0)}{2} U_{1}^{\prime}(x)+\frac{\varphi_{1}(0)+i \varphi_{2}(0)}{2} U_{2}^{\prime}(x)- \\
& -\frac{M_{1}(0)+i M_{2}(0)}{2} U_{3}^{\prime}(x)-\frac{Q_{1}(0)+i Q_{2}(0)}{2} U_{4}^{\prime}(x)+\frac{1}{2(1+i \gamma)} U_{5}^{\prime}(x) \\
& \frac{M_{1}(x)+i M_{2}(x)}{2}=-E(x) I(x)\left(\frac{y_{1}(0)+i y_{2}(0)}{2} U_{1}^{\prime \prime}(x)+\frac{\varphi_{1}(0)+i \varphi_{2}(0)}{2} U_{2}^{\prime \prime}(x)-\right. \\
& \left.-\frac{M_{1}(0)+i M_{2}(0)}{2} U_{3}^{\prime \prime}(x)-\frac{Q_{1}(0)+i Q_{2}(0)}{2} U_{4}^{\prime \prime}(x)+\frac{1}{2(1+i \gamma)} U_{5}^{\prime \prime}(x)\right) \\
& \frac{Q_{1}(x)+i Q_{2}(x)}{2}=-\frac{y_{1}(0)+i y_{2}(0)}{2}\left(E(x) I(x) U_{1}^{\prime \prime}(x)\right)^{\prime}- \\
& -\frac{\varphi_{1}(0)+i \varphi_{2}(0)}{2}\left(E(x) I(x) U_{2}^{\prime \prime}(x)\right)^{\prime}+\frac{M_{1}(0)+i M_{2}(0)}{2}\left(E(x) I(x) U_{3}^{\prime \prime}(x)\right)^{\prime}+ \\
& +\frac{Q_{1}(0)+i Q_{2}(0)}{2}\left(E(x) I(x) U_{4}^{\prime \prime}(x)\right)^{\prime}-\frac{1}{2(1+i \gamma)}\left(E(x) I(x) U_{5}^{\prime \prime}(x)\right)^{\prime} .
\end{aligned}
$$

So, the complex functions, which real part is the components $y_{1}(x), \varphi_{1}(x), M_{1}(x), Q_{1}(x)$, are found, and the imaginary part are the components $y_{2}(x), \varphi_{2}(x), M_{2}(x), Q_{2}(x)$. Adapted to circumstances, we will distinguish the real and imaginary components of dynamic parameters (5) - (8).

$U_{n}(x)=\operatorname{Re} U_{n}(x)+i \operatorname{Im} U_{n}(x)(n=1,2,3,4,5)$ are used and the right members of the formulas (42) - (45) are transformed, having allocated there the real and imaginary parts. As a result, for the real components of dynamic parameters we will receive:

$$
\begin{aligned}
& y_{1}(x)=y_{1}(0) \operatorname{Re} U_{1}(x)+\varphi_{1}(0) \operatorname{Re} U_{2}(x)-M_{1}(0) \operatorname{Re} U_{3}(x)-Q_{1}(0) \operatorname{Re} U_{4}(x)- \\
& -y_{2}(0) \operatorname{Im} U_{1}(x)-\varphi_{2}(0) \operatorname{Im} U_{2}(x)+M_{2}(0) \operatorname{Im} U_{3}(x)+Q_{2}(0) \operatorname{Im} U_{4}(x)+ \\
& +\frac{1}{1+\gamma^{2}}\left(\operatorname{Re} U_{5}(x)+\gamma \operatorname{Im} U_{5}(x)\right) ; \\
& \varphi_{1}(x)=y_{1}(0) \operatorname{Re} U_{1}^{\prime}(x)+\varphi_{1}(0) \operatorname{Re} U_{2}^{\prime}(x)-M_{1}(0) \operatorname{Re} U_{3}^{\prime}(x)-Q_{1}(0) \operatorname{Re} U_{4}^{\prime}(x)- \\
& -y_{2}(0) \operatorname{Im} U_{1}^{\prime}(x)-\varphi_{2}(0) \operatorname{Im} U_{2}^{\prime}(x)+M_{2}(0) \operatorname{Im} U_{3}^{\prime}(x)+Q_{2}(0) \operatorname{Im} U_{4}^{\prime}(x)+ \\
& +\frac{1}{1+\gamma^{2}}\left(\operatorname{Re} U_{5}^{\prime}(x)+\gamma \operatorname{Im} U_{5}^{\prime}(x)\right) ;
\end{aligned}
$$




$$
\begin{aligned}
& M_{1}(x)=-E(x) I(x)\left[y_{1}(0) \operatorname{Re} U_{1}^{\prime \prime}(x)+\varphi_{1}(0) \operatorname{Re} U_{2}^{\prime \prime}(x)-M_{1}(0) \operatorname{Re} U_{3}^{\prime \prime}(x)-\right. \\
& -Q_{1}(0) \operatorname{Re} U_{4}^{\prime \prime}(x)-y_{2}(0) \operatorname{Im} U_{1}^{\prime \prime}(x)-\varphi_{2}(0) \operatorname{Im} U_{2}^{\prime \prime}(x)+M_{2}(0) \operatorname{Im} U_{3}^{\prime \prime}(x)+ \\
& \left.+Q_{2}(0) \operatorname{Im} U_{4}^{\prime \prime}(x)+\frac{1}{1+\gamma^{2}}\left(\operatorname{Re} U_{5}^{\prime \prime}(x)+\gamma \operatorname{Im} U_{5}^{\prime \prime}(x)\right)\right] \\
& Q_{1}(x)=-y_{1}(0)\left(E(x) I(x) \operatorname{Re} U_{1}^{\prime \prime}(x)\right)^{\prime}-\varphi_{1}(0)\left(E(x) I(x) \operatorname{Re} U_{2}^{\prime \prime}(x)\right)^{\prime}+ \\
& +M_{1}(0)\left(E(x) I(x) \operatorname{Re} U_{3}^{\prime \prime}(x)\right)^{\prime}+Q_{1}(0)\left(E(x) I(x) \operatorname{Re} U_{4}^{\prime \prime}(x)\right)^{\prime}+ \\
& +y_{2}(0)\left(E(x) I(x) \operatorname{Im} U_{1}^{\prime \prime}(x)\right)^{\prime}+\varphi_{2}(0)\left(E(x) I(x) \operatorname{Im} U_{2}^{\prime \prime}(x)\right)^{\prime}- \\
& -M_{2}(0)\left(E(x) I(x) \operatorname{Im} U_{3}^{\prime \prime}(x)\right)^{\prime}-Q_{2}(0)\left(E(x) I(x) \operatorname{Im} U_{4}^{\prime \prime}(x)\right)^{\prime}- \\
& -\frac{1}{1+\gamma^{2}}\left(\left(E(x) I(x) \operatorname{Re} U_{5}^{\prime \prime}(x)\right)^{\prime}+\gamma\left(E(x) I(x) \operatorname{Im} U_{5}^{\prime \prime}(x)\right)^{\prime}\right) .
\end{aligned}
$$

For imaginary components of dynamic parameters we will have:

$$
\begin{aligned}
& y_{2}(x)=y_{2}(0) \operatorname{Re} U_{1}(x)+\varphi_{2}(0) \operatorname{Re} U_{2}(x)-M_{2}(0) \operatorname{Re} U_{3}(x)-Q_{2}(0) \operatorname{Re} U_{4}(x)+ \\
& +y_{1}(0) \operatorname{Im} U_{1}(x)+\varphi_{1}(0) \operatorname{Im} U_{2}(x)-M_{1}(0) \operatorname{Im} U_{3}(x)-Q_{1}(0) \operatorname{Im} U_{4}(x)+ \\
& +\frac{1}{1+\gamma^{2}}\left(\operatorname{Im} U_{5}(x)-\gamma \operatorname{Re} U_{5}(x)\right) \\
& \varphi_{2}(x)=y_{2}(0) \operatorname{Re} U_{1}^{\prime}(x)+\varphi_{2}(0) \operatorname{Re} U_{2}^{\prime}(x)-M_{2}(0) \operatorname{Re} U_{3}^{\prime}(x)-Q_{2}(0) \operatorname{Re} U_{4}^{\prime}(x)+ \\
& +y_{1}(0) \operatorname{Im} U_{1}^{\prime}(x)+\varphi_{1}(0) \operatorname{Im} U_{2}^{\prime}(x)-M_{1}(0) \operatorname{Im} U_{3}^{\prime}(x)-Q_{1}(0) \operatorname{Im} U_{4}^{\prime}(x)+ \\
& +\frac{1}{1+\gamma^{2}}\left(\operatorname{Im} U_{5}^{\prime}(x)-\gamma \operatorname{Re} U_{5}^{\prime}(x)\right) ; \\
& M_{2}(x)=-E(x) I(x)\left[y_{2}(0) \operatorname{Re} U_{1}^{\prime \prime}(x)+\varphi_{2}(0) \operatorname{Re} U_{2}^{\prime \prime}(x)-M_{2}(0) \operatorname{Re} U_{3}^{\prime \prime}(x)-\right. \\
& -Q_{2}(0) \operatorname{Re} U_{4}^{\prime \prime}(x)+y_{1}(0) \operatorname{Im} U_{1}^{\prime \prime}(x)+\varphi_{1}(0) \operatorname{Im} U_{2}^{\prime \prime}(x)-M_{1}(0) \operatorname{Im} U_{3}^{\prime \prime}(x)- \\
& \left.-Q_{1}(0) \operatorname{Im} U_{4}^{\prime \prime}(x)+\frac{1}{1+\gamma^{2}}\left(\operatorname{Im} U_{5}^{\prime \prime}(x)-\gamma \operatorname{Re} U_{5}^{\prime \prime}(x)\right)\right] \\
& Q_{2}(x)=-y_{2}(0)\left(E(x) I(x) \operatorname{Re} U_{1}^{\prime \prime}(x)\right)^{\prime}-\varphi_{2}(0)\left(E(x) I(x) \operatorname{Re} U_{2}^{\prime \prime}(x)\right)^{\prime}+ \\
& +M_{2}(0)\left(E(x) I(x) \operatorname{Re} U_{3}^{\prime \prime}(x)\right)^{\prime}+Q_{2}(0)\left(E(x) I(x) \operatorname{Re} U_{4}^{\prime \prime}(x)\right)^{\prime}- \\
& -y_{1}(0)\left(E(x) I(x) \operatorname{Im} U_{1}^{\prime \prime}(x)\right)^{\prime}-\varphi_{1}(0)\left(E(x) I(x) \operatorname{Im} U_{2}^{\prime \prime}(x)\right)^{\prime}+ \\
& +M_{1}(0)\left(E(x) I(x) \operatorname{Im} U_{3}^{\prime \prime}(x)\right)^{\prime}+Q_{1}(0)\left(E(x) I(x) \operatorname{Im} U_{4}^{\prime \prime}(x)\right)^{\prime}- \\
& -\frac{1}{1+\gamma^{2}}\left(\left(E(x) I(x) \operatorname{Im} U_{5}^{\prime \prime}(x)\right)^{\prime}-\gamma\left(E(x) I(x) \operatorname{Re} U_{5}^{\prime \prime}(x)\right)^{\prime}\right) .
\end{aligned}
$$

For the sake of clarity it was necessary to indicate the real and imaginary parts at functions $U_{n}(x)(n=1,2,3,4,5)$ in an explicit form. As a result we will present number $\lambda^{2}$ in a trigonometrical form.

On the basis of trigonometrical form of numbers' designation $1-i v$ and $1+i \gamma$, for number $\lambda^{2}$ we will have

$$
\lambda^{2}=\theta^{2} \frac{1-i v}{1+i \gamma}=\theta^{2} \sqrt{\frac{1+v^{2}}{1+\gamma^{2}}}(\cos \delta-i \sin \delta),
$$


where $\delta=\operatorname{arctg} v+\operatorname{arctg} \gamma$. Thus any natural degree $k$ of number $\lambda^{2}$ can be calculated, having used Moivre formula

$$
\lambda^{2 k}=\theta^{2 k}\left(\frac{1+v^{2}}{1+\gamma^{2}}\right)^{\frac{k}{2}}(\cos k \delta-i \sin k \delta) .
$$

As a result, for the fundamental solutions (18) and function (36), taking into account (54), we receive

$$
\begin{aligned}
& U_{n}(x)=b_{n, 0}(x)+\sum_{k=1}^{\infty} \lambda^{2 k} b_{n, k}(x)=b_{n, 0}(x)+\sum_{k=1}^{\infty} \Theta^{2 k} \cos k \delta b_{n, k}(x)-i \sum_{k=1}^{\infty} \Theta^{2 k} \sin k \delta b_{n, k}(x) \\
& (n=1,2,3,4,5),
\end{aligned}
$$

where $\Theta=\theta \sqrt[4]{\frac{1+v^{2}}{1+\gamma^{2}}}$.

Thus, the dynamic parameters of the core are completely determined by formulas (5) (8), (46) - (53). Be it noted that these formulas contain unknown constants in the form of initial values of the real and imaginary components (initial parameters). For instance, the exact solution of differential equation of the forced transverse harmonic vibrations of the core taking into account the resistance (4), which is given by formulas (5), (46), (50), is found.

At last we will notice that in practice for the research of vibrations instead of formulas (5) - (8) it is effectually to use formulas equivalent to them:

$$
\begin{aligned}
& y(x, t)=y(x) \sin \left(\theta t+\chi_{y}(x)\right), y(x)=\sqrt{y_{1}^{2}(x)+y_{2}^{2}(x)}, \quad \chi_{y}(x)=\operatorname{arctg} \frac{y_{2}(x)}{y_{1}(x)} \\
& \varphi(x, t)=\varphi(x) \sin \left(\theta t+\chi_{\varphi}(x)\right), \varphi(x)=\sqrt{\varphi_{1}^{2}(x)+\varphi_{2}^{2}(x)}, \quad \chi_{\varphi}(x)=\operatorname{arctg} \frac{\varphi_{2}(x)}{\varphi_{1}(x)} \\
& M(x, t)=M(x) \sin \left(\theta t+\chi_{M}(x)\right), M(x)=\sqrt{M_{1}^{2}(x)+M_{2}^{2}(x)}, \chi_{M}(x)=\operatorname{arctg} \frac{M_{2}(x)}{M_{1}(x)} \\
& Q(x, t)=Q(x) \sin \left(\theta t+\chi_{Q}(x)\right), Q(x)=\sqrt{Q_{1}^{2}(x)+Q_{2}^{2}(x)}, \quad \chi_{Q}(x)=\operatorname{arctg} \frac{Q_{2}(x)}{Q_{1}(x)}
\end{aligned}
$$

Advantage of formulas (55) - (58) is that amplitude functions of the dynamic parameters are obviously distinguished in them.

\section{CONCLUSIONS}

In this work the differential equation of the forced transverse vibrations of the core with any continuous variable parameters, loaded evenly by the distributed harmonic load is integrated for the first time. As a result, in an analytic form the formulas are received which allow to define the forced dynamic vibrations $y(x, t), \varphi(x, t)$ and dynamic internal forces $M(x, t), Q(x, t)$ from harmonic loading $q(x, t)=q(x) \sin \theta t$, where the task at any fixing of the core is to search unknown initial parameters.

The solution of this problem opens a prospect for creation of a new research technique of transverse vibrations of the cores with any continuous parameters taking into account resistances. For this purpose it is enough to indicate an efficient method of numerical implementation of the exact solutions.

\section{References}

1. Babakov, M. A. (1976). Teoriya kolebaniy. M.: Nauka, 592. 
2. Danylevych, T. Ye., Senyk, A. P. (2006). Vymusheni kolyvannya vala z yihnim pasyvnym pohlynachem. Avtomatyzatsiya vyrobnychykh prothesiv $u$ mashynobuduvanni ta pryladobuduvanni: mizhvidomchyi naukovo-tekhnichnyi zbirnyk, 40, 84-87.

3. Halas, O. S. (2008). Rozrobka metodiv analizy ta hasinnya neliniynykh kolyvan' sterzhnevykh system. Abstract to Ph. D. thesis.

4. Maslov, G. S. (1968). Raschety kolebaniy valov. M.: Mashynostroyenie, 220.

5. Svetlitskiy, V. A. (1987). Mehanika sterzhney. Uchebnik dlya vtuzov. V 2 ch. 4.1. Statika. M.: Vysshaya shkola, 320.

6. Svetlitskiy, V. A. (1987). Mehanika sterzhney. Uchebnik dlya vtuzov. V 2 ch. 4.2. Dinamika. M.: Vysshaya shkola, 304.

7. Kharchenko, Ye. V., Kvashenko, O. I. (2003). Rozrakhunok nestatsinarnykh kolyvan' strymuval'nykh konstruktsiy zminnoyi dovzhyny. Proekruvannya, vyrobnytstvo ta ekspluatatsiya avtotransportnykh zasobiv i poyizdiv: zbirnyk naukovykh prats', 7, 170-174.

8. Kharchenko, Ye. V. (2004). Rozrakhunok pozdovzhnyo-poperechnykh kolyvan' strymuval'nykh konstruktsiy znachnoyi dovzhyny zi zminnymy pruzhno-inertsiynymy kharacterystykamy. Pozhezhna bezpeka: zbirnyk naukovykh prats, 4, 187-193.

9. Kharchenko, O., Pidhaynyi, T. (2009). Matematychne modeliuvannya vil'nykh pozdovzhnyopoperechnykh kolyvan' skladenoho tryzhnya. Proceedings of the 9th International Symposium of Ukrainian Mechanical Engineers, 63-64.

10.Shevchenko, F. L. (2006). Uproschennyi dinamicheskiy raschet sterzhnevykh sistem s raspredelennymi parametrami. Avtomatyzatsiya vyrobnychykh protsesiv u mashynobuduvanni ta pryladobuduvanni: mizhvidomchyi naukovo-technichnyi zbirnyk, 40, 278-285.

11.Kiselev, V. A. (1980). Stroitelnaya mehanika. M.: Stroyizdat, 616.

12.Babakov, I. M. (2004). Teoriya kolebaniy. M.: Drofa, 591.

13.Tymoshenko, S. P., Young, D. H., Uiver, U. (1985). Kolebaniya v inzhenernov dele. M.: Mashynostroyenie, 1985. $-472 \mathrm{c}$.

14.Dinnik, A. N. (1955). Prodolnyi izgib. Krucheniye. M.: Publishing House of the USSR Academy of Sciences, 392.

15.Vasylenko, M. V. (2004). Teoriya kolyvan' i stiykosti ruhu. K.: Vyscha shkola, 525.

16.Sorokin, E. S. (1960). K teorii vnutrennego treniya pri kolebaniyah uprugih sistem. M.: Gosstroyizdat, 131.

17.Gantmaher, F. .R. (1988). Teoriya matrits. M.: Nauka, 552.

\section{Література}

1. Бабаков И. М. Теория колебаний / И. М. Бабаков - М.: Наука, 1976. - 592 с.

2. Данилевич Т. Є. Вимушені поперечні коливання вала з їхнім пасивним поглиначем / Т. Є. Данилевич, А. П. Сеник // Автоматизація виробничих процесів у машинобудуванні та приладобудуванні: міжвідомчий науково-технічний збірник. - 2006. - № 40. - С. 84-87.

3. Галас О. С. Розробка методів аналізу та гасіння нелінійних коливань стержневих систем: автореф. Дис. на здобуття наук. ступеня канд. Техн.. наук: спец. 01.02.04 «Механіка деформівного твердого тіла» / Галас Олег Сергійович; Нац. академія наук України інститут проблем машинобудування ім. А. М. Підгорного. - Харків - 2008. - 21 с.

4. Маслов Г. С. Расчеты колебаний валов // Справочное пособие. - М.: Машиностроение, 1968. $-220 \mathrm{c}$.

5. Светлицкий В. А. Механика стержней. Учебник для втузов. В 2-х ч. 4.1. Статика / В. А. Светлицкий. - М.: Высшая школа, 1987. - 320 с.

6. Светлицкий В. А. Механика стержней. Учебник для втузов. В 2-х ч. 4.2. Динамика / В. А. Светлицкий. - М.: Высшая школа, 1987. - 304 с.

7. Харченко Є. В. Розрахунок нестаціонарних коливань стримувальних конструкцій змінної довжини / Є. В. Харченко, О. І Квашенко. // Проектування, виробництво та експлуатація автотранспортних засобів і поїздів: збірник наукових праць. - 2003. - Вип. 7. - С. 170-174.

8. Харченко Є. В. Розрахунок поздовжньо-поперечних коливань стримувальних конструкцій значної довжини зі змінними пружно-інерційними характеристиками / Є. В. Харченко, А. М. Петренко // Пожежна безпека: збірник наукових праць. - 2004. - № 4. - С. 187-193. 
9. Харченко О. Математичне моделювання вільних поздовжньо-поперечних коливань складеного стрижня / О. Харченко, Т. Підгайний // Праці 9-ого міжнародного симпозіуму українських інженерів-механіків у Львові. - 2009. - С. 63-64.

10.Шевченко Ф. Л. Упрощенный динамический расчет стержневых систем с распределенными параметрами / Ф. Л. Шевченко // Автоматизація виробничих процесів у машинобудуванні та приладобудуванні: міжвідомчий науково-технічний збірник. - 2006. - № 40. - С. 278-285.

11.Киселев В. А. Строительная механика / В. А Киселев - М.: Стройиздат, 1980. - 616 с.

12.Бабаков И. М. Теория колебаний / И. М. Бабаков - М.: Дрофа, 2004. - 591 с.

13.Тимошенко С. П. Колебания в инженерном деле / С П. Тимошенко, Д. Х. Янг, У. Уивер М.: Машиностроение, 1985. - 472 с.

14.Динник А. Н. Продольный изгиб. Кручение. / А. Н. Динник - М.: Издательство академии наук СССР, 1955. - 392 с.

15.Василенко М. В. Теорія коливань і стійкості руху / М. В. Василенко, О. М. Алексейчук - К. : Вища школа, 2004. - 525 с.

16.Сорокин Е. С. К теории внутреннего трения при колебаниях упругих систем / Е. С. Сорокин - М.: Госстройиздат, 1960. - 131 с.

17. Гантмахер Ф. Р. Теория матриц / Ф. Р. Гантмахер - М.: Наука, 1988. - 552 с.

\section{Krutii Yurii}

Odessa State Academy of Civil Engineering and Architecture, Doctor of Technical Science, professor Didrihsona str.,4 Odessa, Ukraine 65029

yurii.krutii@gmail.com

ORCID:0000-0001-7105-3087

\section{Surianinov Mykola}

Odessa State Academy of Civil Engineering and Architecture, Doctor of Technical Science, professor Didrihsona str.,4 Odessa, Ukraine 65029

sng@ogasa.org.ua

ORCID:0000-0003-2592-5221

\section{Osadchiy Vladimir}

Odessa State Academy of Civil Engineering and Architecture, Ph.D., associate professor

Didrihsona str.,4 Odessa, Ukraine 65029

Ovs1455@gmail.com

ORCID:0000-0001-8153-8635

For references:

Krutii, Yu., Surianinov, M., Osadchiy, V. (2019). The exact solution of the differential equation of the compelled cross vibrations of the core with any continuous parameters. Mechanics and Mathematical Methods, 2, $46-61$.

\section{Для посилань.}

Крутій Ю. С. Точний розв'язок диференціального рівняння вимушених поперечних коливань стрижня 3 довільними неперервними параметрами / Ю. С. Крутій, М. Г. Сур'янінов, В С. Осадчий // Механіка та математичні методи. - 2019. - №2. - С. 46-61. 